\title{
Evaluation of Antifungal and Enzymatic Potential of Endophytic Fungi Isolated from Cupressus torulosa D. Don
}

\section{Mohd Mahfooz ${ }^{1}$, Sushmita Dwedi ${ }^{1}$, Arun Bhatt ${ }^{1}$, Sharad Raghuvanshi ${ }^{1}$, Manoj Bhatt ${ }^{2}$ and Pavan Kumar Agrawal ${ }^{1 *}$}

\author{
${ }^{1}$ Department of Biotechnology, G.B. Pant Engineering College, Ghurdauri, Pauri, Garhwal, \\ Uttarakhand, India \\ ${ }^{2}$ Guru Gobind Singh Indraprastha University, Delhi, India \\ *Corresponding author
}

\section{A B S T R A C T}

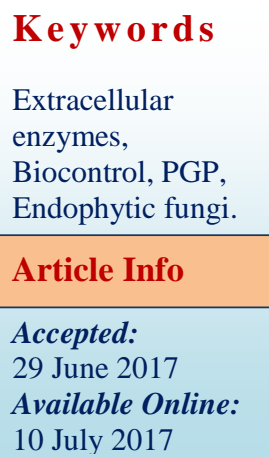

\section{Introduction}

The term endophyte is applied to fungi or bacteria which live within plant tissues, for all or part of their life cycle and causes no apparent infections (Wilson, 2000). Like other organisms invading plant tissues, endophytic fungi produce extracellular hydrolases as a resistance mechanism against pathogenic invasion and to obtain nutrition from host. Such enzymes include pectinases, cellulases, lipases, laccase from the endophytic fungus Monotospora sp., xylanase, -1, 4glucanlyase, phosphotases and proteinase (Sunitha et al., 2013). Hydrolytic enzymes (amylase, proteases, cellulases, chitansae and laccase) with various industrial applications are also of major interest.

Biological control through microorganisms which inhibit or antagonize plant pathogens and pests reduces or eliminates the use of chemical products. Fungal endophytes are effective antagonists (Azevedo et al., 2000) and constitute a taxonomically and metabolically diverse group of organisms that colonize internal plant tissues without causing apparent harm to the host plant. Indeed, endophyte-mediated biological control has been investigated both in vivo and in vitro 
through screening experiments to verify the activity of endophytes against phytopathogens and pests (Flores et al., 2013).

Endophytic and phytopathogenic fungi compete and interact within the same ecological niche through the action of hydrolytic enzymes such as proteases and chitinases, which degrade the hyphal cell walls of pathogenic microorganisms (Almeida et al., 2007). This enzymatic activity is closely associated with the fungus-host specificity. To facilitate the entry of endophytes into host tissues through natural or artificial openings, hydrolytic enzymes including pectinases, cellulases and lipases are secreted (Polizeli et al., 1991).

It has been observed that some strains of bacteria and fungi shows beneficial effects on plants and this type of evaluation is based on better emergence of seedling's fast growth. The mechanism of plant growth promotion include, i] solubilization of insoluble phosphates (ii) ability to produce phytoharmone auxin iii) production of $\mathrm{HCN}$ iv) siderophore production. The Plant growth promoting activity of microorganism showed beneficial association with the plants by increasing uptake of $\mathrm{N}, \mathrm{P}$ and Fe (Kloepper et $a l ., 2009)$. There are many reports on the use of micro-organisms as biocontrol agents as an alternate to agricultural chemical fungicides (Kaur et al., 2013).

In present investigation, considering the shortage of information concerning the antifungal and enzymatic activities of the endophytes from this plant, the aim of the present study was to evaluate the antagonism interactions between endophytic fungi and phytopathogenic fungi in dual culture experiments and to detect the extracellular enzyme activity of these fungal endophytes isolated from Cupressus torulosa D. Don using a plate assay and different growth substrates.

\section{Materials and Methods}

\section{Isolation of endophytic fungi}

The sampling procedure was designed with the intention of isolating as many endophytic fungal species as possible from the different tissues samples. Tissues of the leaves of Cupressus torulosa D. Don were cut into 5 $\mathrm{mm}$ long segments. Surface sterilization followed the method of (Arnold et al., 2007) with minor modification.

Segments were surface sterilized by consecutive immersion for $1 \mathrm{~min}$ in $75 \%$ Ethanol, treated for $1 \mathrm{~min}$ in $0.1 \%$ mercuric chloride, followed by several washing in sterile distilled water (Sharma et al., 2016). The time of the dilution and immersion in ethanol and Mercuric chloride varies with tissues and host (At least three washing require).

Under sterile conditions, tissue segments were allowed to surface-dry before plating. Five segments were then evenly placed in each 90 $\mathrm{mm}$ Petri dish containing Potato dextrose agar and water agar Medium. The dishes were sealed with parafilm and incubated at $27^{\circ} \mathrm{C} \pm$ $2^{\circ} \mathrm{C}$ for 2-4 weeks in incubator.

Fungal growth was observed from the tissues segments inoculated on the different media plates as colored cottony outgrowth. Hyphal tips, from germinating fungi, were isolated, sub cultured onto PDA and brought into pure culture by incubating at $28^{\circ} \mathrm{C}$ for $5-7$ days.

The purified fungal isolates were maintained at $4^{\circ} \mathrm{C}$. The cultures were also submitted to the Gujarat State Biotechnology Mission microbial repository for preservation. 


\section{Preservation of endophytic fungi cultures}

\section{PDA slants}

The PDA slants were inoculated with hyphal tips taken from the PDA plates. The slants were incubated at $28^{\circ} \mathrm{C}$ for 5-7 days to observe the growth of pure culture of fungal endophyte. This was followed by refrigeration of the slants at $4^{\circ} \mathrm{C}$.

\section{$20 \%$ glycerol}

Mycelial agar plugs were placed in sterile cryovials containing PDB with 20\% glycerol under sterile laminar conditions and stored at $-80^{\circ} \mathrm{C}$.

\section{Identification of endophytic fungi}

Fungal growth and sporulation was facilitated by placing the isolates onto PDA culture medium. The plates were continuously monitored for spore formation. Isolates were identified on the basis of cultural characteristics, colour and morphology of fruiting bodies and spores. Fungal isolates were stained with lactophenole cotton blue and examined under light microscope (Olympus, USA).

\section{Metabolic activity of fungal endophytes}

\section{Screening for secretion of amylase}

To test for the production of amylase, endophytes were inoculated on glucose yeast extract peptone (GYP) agar medium (glucose $1 \mathrm{~g}$, yeast extract $0.1 \mathrm{~g}$, peptone $0.5 \mathrm{~g}$, agar 15 $\mathrm{g}$, and distilled water $1000 \mathrm{~mL}, \mathrm{pH}$ 6) containing $1 \%$ soluble starch. After incubating for 5 days, $1 \%$ iodine in $2 \%$ potassium iodide was flooded in the fungal colony plates. A clear zone appearance surrounding the colony was considered positive for amylase enzyme (Bhardwaj et al., 2015).

\section{Screening for secretion of protease}

Protease assay was performed by growing the fungi on GYP media amended with $1 \%$ skim milk and $\mathrm{pH}$ was adjusted to 6.5 , after 5 days incubation the clear zone appeared around the fungal colony indicated the presence of protease enzyme.

\section{Screening for secretion of lipase}

For lipase activity measurement, the fungus were grown on Peptone Agar Medium (Peptone 10 g, NaCl 5 g, Agar 16 g, Distilled water: $1000 \mathrm{ml}$ and $\mathrm{pH}$ 6) supplemented with $1 \% \mathrm{w} / \mathrm{v}$ tween 20 (separately sterilized). A clear zone around the colony indicated the presence of lipase enzyme.

\section{Screening for secretion of cellulase}

For Cellulase test, GYP Agar media was used as the medium to grow the fungus. To GYP agar media, 1\% CMC (carboxy methyl cellulose) was added which act as a substrate. After 4 days of incubation at $27^{\circ} \mathrm{C}$, the plates were flooded with $0.2 \%$ of aqueous Congo red solution for 20 minutes and distained with $1 \mathrm{M} \mathrm{NaCl}$ for $15 \mathrm{~min}$. Appearance of yellow areas around the fungal colony indicates the presence of cellulase activity.

\section{Screening for secretion of chitinase}

The final chitinase detection medium consisted of a basal medium comprising (all amounts are per litre) $4.5 \mathrm{~g}$ of colloidal chitin, $0.3 \mathrm{~g}$ of $\mathrm{MgSO}_{4} .7 \mathrm{H}_{2} \mathrm{O}, 3 \mathrm{~g}$ of $\left(\mathrm{NH}_{4}\right) \mathrm{SO}_{4}, 2 \mathrm{~g}$ of $\mathrm{KH}_{2} \mathrm{PO}_{4}, 1 \mathrm{~g}$ of citric acid monohydrate, 15 $\mathrm{g}$ of agar, $0.15 \mathrm{~g}$ of bromocresol purple and $200 \mu \mathrm{l}$ of tween-80, $\mathrm{pH}$ was adjusted to 4.7 and then autoclaved at $121^{\circ} \mathrm{C}$ for $15 \mathrm{~min}$. After cooling the media was poured in to petri plates and allowed to solidify. The fresh culture plugs of the isolates to be tested for chitinase activity was inoculated into the 
medium and incubated at $27^{\circ} \mathrm{C}$ for $2-3 \mathrm{~d}$ and observed for colored zone formation. Chitinase activity was identified due to the formation purple colored zone.

\section{Plant growth promoting attribute of fungal endophytes}

\section{Phosphate solubilising activity}

The fungal cultures were inoculated on centre of Pikovskaya's medium under aseptic. Inoculated plates were incubated for 7-10 days at $27^{\circ} \mathrm{C}$. The clear zone around the colony showed positive phosphate solubilisation ability (Agrawal and Agrawal, 2013).

\section{Production of ammonia}

Fungal isolates were tested for the production of ammonia peptone water is used. In each tube of $10 \mathrm{ml}$ peptone water freshly grown cultures were inoculated and incubated for $48-72 \mathrm{~h}$ at $27^{\circ} \mathrm{C}$.

Nessler's reagent $0.5 \mathrm{ml}$ of was added in each tube. Development of brown to yellow colour indicate positive test for ammonia production.

\section{Production of $\mathrm{HCN}$}

For $\mathrm{HCN}$ production, fungal isolates were screen for the production of hydrogen cyanide by adapting the method of Lorck (1948).

Briefly nutrient broth was amended with $4.4 \mathrm{~g}$ glycine/l and fungal streaked on modified agar plate. Then a Whatman filter paper No.1 soaked in $0.5 \%$ picric acid and $2 \% \mathrm{Na}_{2} \mathrm{CO}_{3}$ was placed in the lid of the Petri dish, which was then sealed with paraffin film. After four days of incubation at $27^{\circ} \mathrm{C}$, yellow to brown disc coloration of the paper indicated $\mathrm{HCN}$ production (Agrawal et al., 2015).

\section{Antagonistic activity of endophytic fungi}

Test pathogens, Aspergillus niger Fusarium solanii and, Fusarium oxysporum were obtained from department of Biotechnology, GBPEC, Pauri, Garhwal, Uttrakhand. Dual culture technique was adopted for antagonistic test against these pathogens on PDA plates. Six-day-old mycelia disks of (5mm diameter) of test pathogens were placed on one corner of Petri plates containing PDA medium. Fungal endophytes were inoculated on the other corner of PDA plates. Plates were incubated at $28^{\circ} \mathrm{C}$ for 6 days and antagonistic index was accessed according to the following formula:

Antagonistic Index: $\frac{\mathrm{RM}-\mathrm{rm}}{\mathrm{RM}} \times 100$

$\mathrm{RM}$ : radius of the pathogen in the control plate

$\mathrm{rm}$ : radius of pathogen in the dual culture plate

\section{Result and Discussion}

A systematic study about the endophytic fungal biodiversity in a forest plant, Cupressus torulosa D. Don. located in Govind Ballabh Pant Engineering College Campus, Pauri Garhwal, Uttarakhand were carried out to evaluate their extracellular enzyme production and it role in biocontrol activity. A total of eight endophytic fungi were isolated from leaves of $C$. torulosa D.Don by using different culture media. These endophytic fungi were characterized morphotypically using lactophenole cotton blue using scotch tape techniques (Table 1). All fungal endophytes were preserved in PDA slants at $4^{\circ} \mathrm{C}$ as well $-80^{\circ} \mathrm{C}$ in glycerol stock for further use.

The Majority of the recovered endophtytes belong to the Ascomycota. Fungal endophytes are especially common among the Ascomycota, representing at least five classes, 
dozens of families, and large numbers of previously unknown species (Sharma et al., 2016). Only one species from the collected isolates in this study belong to the Dothideomycetes (Petrini, 1986).

\section{Functional attributes of fungal endophytes}

The relationship between the endophyte and its host plant may range from latent phytopathogenesis to mutualistic symbiosis (Panutahi et al., 2012). Like other organisms invading plant tissues, endophytic fungi produce extracellular hydrolases (Table 2) as a resistance mechanism against pathogenic invasion and to obtain nutrition from host. Such enzymes include pectinases, cellulases, lipases, laccase from the endophytic fungus Monotospora sp., $\quad$ xylanase, $\quad-1, \quad 4-$ glucanlyase, phosphotases and proteinase (Sunitha et al., 2013). Hydrolytic enzymes (amylase, cellulase and laccase) with various industrial applications are also of major interest. Hydrolases also reported from Pinus rouxburghii by Bhardwaj et al., (2015)

\section{Amylase activity}

All fungal endophytes were able to produce extracellular amylase (Fig. 1). The amylolytic potential of these endophytes may help them to degrade starch which is available when the plant senesces. The isolate KCTS34 was show highest amylase activity with the diameter of $76 \mathrm{~mm}$ The Amylase activity was found to be higher with Tuber aestivum than with Tuber maculatum (Nadim et al., 2015). Rhizoctonia $s p$. showed highest production of amylase enzyme i.e. 0.26U/ml (Patil et al., 2015). Endophytic fungi such as Penicillium frequentans isolated from Pinus rouxburghii were screened for amylolytic activity. Influence of various physical and chemical factors such as $\mathrm{pH}$, temperature, carbon and nitrogen sources on amylase production by $P$. frequentans in liquid media was studied (Bhardwaz et al., 2015). The maximal amylase productivity achieved at $30^{\circ} \mathrm{C}$ of incubation was $0.28 \mu / \mathrm{ml}$ and maximum fungal biomass was $5.618 \mathrm{~g} / 25 \mathrm{ml}$ and at $\mathrm{pH}$ 7.0 of the cultural media showed maximum amylase activity of $0.461 \mu / \mathrm{ml}$ and the maximum fungal biomass production was $5.511 \mathrm{~g} / 25 \mathrm{ml}$.

\section{Protease activity}

Out of eight a four $\mathrm{x}$ endophytes exhibited protease activity (Fig. 2). The protease activity was observed in Biosporus sp., Aspergillus sp., Cladosporium sp., Curvularia sp., Rhizoctonia sp., Chaetomium sp., Cladosporium sp. indicated by formation of clear zone around the colony because of degradation of gelatin, while other two isolates Colletotrichum sp., Fusarium sp. from the medicinal plants Citrus limon and Gossypium hirsutum respectively indicated negative results. Similar result was reported by Pavithra et al., 2012, where out fungal isolates from Ocimum sanctum were found positive for protease.

\section{Lipase activity}

These all eight isolates were screened for lipase activity seven isolates such as WCTS21, WCTS33, PCTS13, PCTS21, PCTS25, KCTS15 and KCTS34 produce lipase activity while one isolate WCTS31 was not produce lipase activity (Fig. 3). The isolate PCTS21 was show highest lipase activity with the diameter of $64 \mathrm{~mm}$. Cladosporium sp. of Phyllanthus emblica medicinal plant was the maximum producer of lipase activity (Patil et al., 2015). Amirita et al., (2012) reported lipolytic activity of Curvularia brachyspora, C. vermiformis, Drechslera hawaiiensis, Colletotrichum falcatum and Phyllosticta sp. isolated from medicinal plants. Venkates agowda et al., (2012) reported lipolytic endophytic fungal isolates from the different oil-bearing seeds. 


\section{Cellulase activity}

All fungal endophytes were able to produce extracellular cellulase (Fig. 4). The isolate KCTS34 was show highest cellulase activity with the diameter of $50 \mathrm{~mm}$. Cellulolytic activity was prominent in Talaromyces emersonii (Ci1), followed by Discosia sp. (Ci 5), of Calophyllum inophyllum and Drechsclera sp. (Cr2) from Catharanthus roseus. The production of cellulase was not significant from isolates of other two plants. Only $32 \%$ of the endophytes tested were able to produce cellulose (Sunitha et al., 2013).

Similar result was reported by (Maria et al., 2005) from mangrove angiosperm isolates. However, 66\% cellulolytic activity was reported by (Choi et al., 2005) from isolates of Brucea javanica. Bezerra et al., (2003) reported $53.84 \%$ cellulolytic activity of endophytes from Opuntiaficus-indica Mill., Cladosporium cladosporioides with maximum activity.

\section{Chitinase activity}

All fungal isolates exhibited the chitinase activity. The isolate PCTS13 showed the highest chitinase activity with the diameter of $53 \mathrm{~mm}$ while the isolate WCTS31 showed the lowest chitinase activity with the diameter of $20 \mathrm{~mm}$. the chitinase activity of $0.00093 \mathrm{U} / \mathrm{mL}$ in Streptomyces sp., which corresponds to a specific activity of $0.050 \mathrm{U} / \mathrm{mg}$ protein, was four times lower than that in S. viridificans (0.0038 U/mL) (Gupta et al., 1995).

As with Trichoderma sp, S. elegans is capable of degrading Rhizoctonia solani cell walls (Morissette et al., 2003) and releases the CWDEs, $\beta$-1,3-glucanases and chitinases, into culture medium amended with $R$. solani cell wall fragments or with chitin as a carbon source (Tweddell et al., 1994).

\section{Plant growth promoting activity of endophytic fungi}

Many endophytes are reported to be capable of nitrogen $(\mathrm{N})$ fixation, solubilization of phosphate, enhance uptake of phosphorus (P), production of siderophores, ACC deaminase, and plant hormones such as auxin, abscisins, ethylene, gibberellins, and indole acetic acid (IAA), which are important for plant growth and development regulation (Selim et al., 2012).

\section{Phosphate solubilizing activity}

Eight isolates were screened for Phosphate solubilizing activity, only six isolates such as WCTS21, WCTS33, PCTS13, KCTS15, PCTS25 AND KCTS34 showed the Phosphate solubilizing activity while two isolates such as WCTS31 and PCTS21 were not produce Phosphate solubilizing activity (Fig. 5 and Table 3).

Nahas (1996) reported that among the microbial group, fungi are more efficient in solubilizing phosphate than bacteria. The highest range was observed in $T$. peudokoningii $(37.45 \pm 2.78$ to $64.32 \pm 2.87)$ $\mu \mathrm{g} / \mathrm{ml}$ followed by $C$. globosum (33.62 \pm 5.92 to $69.32 \pm 3.21) \quad \mu \mathrm{g} / \mathrm{ml}, \quad F$. semitectum $(32.64 \pm 1.89$ to $57.63 \pm 2.11) \mu \mathrm{g} / \mathrm{ml}, \quad A$. versicolor $(31.63 \pm 2.02$ to $63.72 \pm 2.36) \mu \mathrm{g} / \mathrm{ml}$ (Chadha et al., 2015).

\section{Production of ammonia}

All fungal isolates exhibited the ammonia production (Fig. 6, Table 3). Most of the ammonia produced by fungi will be transformed to ammonium in solution. However, at higher $\mathrm{pH}$ a larger proportion of the ammonium becomes toxic unionized ammonia; the approximate ratios of $\mathrm{NH}_{3}{ }^{+} \%$ to $\mathrm{NH}_{3}$ will be $1800: 1$ at $\mathrm{pH}$ 6, and 9:1 at $\mathrm{pH}$ $8 \pm 3$. Ammonia is very toxic because it is lipid 
soluble and raises intracellular $\mathrm{pH}$, thus inhibiting protein synthesis and enzyme activity (Doyle and Butler, 1990).

\section{Production of $\mathrm{HCN}$}

All eight fungal endophytes isolates screened for the production of $\mathrm{HCN}$ and any isolates was not produce $\mathrm{HCN}$. $\mathrm{HCN}$ is the common secondary metabolite produced by rhizosphere Pseudomonas (Schippers, 1988). Meena et al., (2001) compared the HCN production of several strains of $P$. fluorescens and their efficacy in controlling root rot of groundnut caused by $M$. phaseolina.

\section{Antagonistic activity of endophytic fungi isolates}

The isolates were tested for antagonistic activity by the dual culture technique. A total of eight endophytic fungal isolates out of seventeen were showed antagonism activity against $A$. niger, $F$. oxyspourm and $F$. solani.
Radial growth of the pathogen was considerably hindered by all the test antagonists under the conditions of this study. WCTS21 was the most antagonistic and inhibited the radial growth of the pathogen most while KCTS34 was the least antagonistic. The fungal isolate PCTS25 was more active against $A$. niger with antagonistic index 75.55 while WCTS31 more active against $F$. oxysporum with antagonistic index 42.18 (Figs. 8, 9 and 10; Table 4) and isolate WCTS2 1 is more active against $F$. solani with antagonistic index 51.66. Aspergillus flavus, A. fumigatus, A. niger, A. sydowi, A. sulphureus, Penicillium sp. and three biocontrol agents namely Trichoderma harzianum, T. Koeningii and T. viride were tested against one plant pathogen namely Pythium debaryanum. The percentage inhibition of growth of pathogen against Trichoderma harzianum, T. koeningii and $T$. viride were $66.6,62.5,60.4$ percentage with respectively (Gomathi et al., 2011).

Table.1 Morphotypic characterization of endophytic fungi

\begin{tabular}{|c|c|c|c|c|}
\hline $\begin{array}{ll}\text { Code } & \text { of } \\
\text { isolate } & \end{array}$ & $\begin{array}{l}\text { Source } \\
\text { Endophytic } \\
\text { Fungi }\end{array}$ & $\begin{array}{l}\text { Colony } \\
\text { charecterstics on } \\
\text { PDA media }\end{array}$ & $\begin{array}{l}\text { Probable } \\
\text { endophytic } \\
\text { fungus }\end{array}$ & Class \\
\hline PCTS13 & Leaves & $\begin{array}{l}\text { Appears olivaceous } \\
\text { brown in colour }\end{array}$ & $\begin{array}{l}\text { Penicillium } \\
\text { oxalicum }\end{array}$ & Ascomycetous \\
\hline PCTS21 & Leaves & $\begin{array}{l}\text { Appears grayish } \\
\text { green in colour }\end{array}$ & $\begin{array}{l}\text { Alternaria } \\
\text { alternata }\end{array}$ & Dothideomycetes \\
\hline KCTS34 & Leaves & $\begin{array}{l}\text { Appears cottony } \\
\text { white in colour }\end{array}$ & Daldinia sp. & Zygomycetes \\
\hline WCTS31 & Leaves & $\begin{array}{l}\text { Whitish } \\
\text { appearance, rapid } \\
\text { growth horizontally }\end{array}$ & $\begin{array}{l}\text { Fusarium } \\
\text { circinatum }\end{array}$ & Sordariomycetes \\
\hline WCTS33 & Leaves & $\begin{array}{l}\text { Whitish } \\
\text { appearance, cotton } \\
\text { growth }\end{array}$ & $\begin{array}{l}\text { Pestalotiopsis } \\
\text { versicolor }\end{array}$ & Sordariomycetes \\
\hline WCTS21 & Leaves & Brown & $\begin{array}{l}\text { Penicillium } \\
\text { megasporum }\end{array}$ & Sordariomycetes \\
\hline
\end{tabular}


Table.2 Extracellular enzymatic activity of endophytic fungi

\begin{tabular}{|c|c|c|c|c|c|c|}
\hline \multirow{2}{*}{ S.NO. } & \multirow{2}{*}{ Isolates } & \multicolumn{6}{|c|}{ Diameter of clear zone (in mm) } \\
\cline { 3 - 7 } & & $\begin{array}{c}\text { Amylase } \\
\text { activity }\end{array}$ & $\begin{array}{c}\text { Protease } \\
\text { activity }\end{array}$ & $\begin{array}{c}\text { Lipase } \\
\text { activity }\end{array}$ & $\begin{array}{c}\text { Cellulase } \\
\text { activity }\end{array}$ & $\begin{array}{c}\text { Chitinase } \\
\text { activity }\end{array}$ \\
\cline { 3 - 7 } & & 30 & 50 & 48 & 48 & 36 \\
\hline 1 & WCTS21 & 65 & 40 & - & 42 & 20 \\
\hline 2 & WCTS31 & 20 & 63 & 60 & 20 & 30 \\
\hline 3 & WCTS33 & 40 & - & 48 & 34 & 53 \\
\hline 4 & PCTS13 & 60 & - & 64 & 50 & 25 \\
\hline 5 & PCTS21 & 54 & - & 52 & 36 & 34 \\
\hline 6 & PCTS25 & 68 & 46 & 30 & 30 & 30 \\
\hline 7 & KCTS15 & 76 & - & 54 & 50 & 26 \\
\hline 8 & KCTS34 & 76 & & & \\
\hline
\end{tabular}

Table.3 Plant growth promoting activity of endophytic fungi

\begin{tabular}{|c|c|c|c|}
\hline Strain/test & $\begin{array}{c}\text { Phosphate solubilizing } \\
\text { activity }\end{array}$ & Production of ammonia & Production of HCN \\
\hline WCTS21 & + & + & - \\
\hline WCTS31 & + & + & - \\
\hline WCTS33 & + & + & - \\
\hline PCTS13 & + & + & - \\
\hline PCTS21 & + & + & - \\
\hline PCTS25 & + & + & - \\
\hline KCTS15 & + & + & \\
\hline KCTS34 & + & & \\
\hline
\end{tabular}

Table.4 Antagonistic activity evaluation of endophytic fungi against fungal pathogens

\begin{tabular}{|l|l|l|l|l|}
\hline \multirow{2}{*}{ S. No. } & \multirow{2}{*}{ Isolates } & \multicolumn{3}{|c|}{ Antagonistic index (\%) } \\
\cline { 3 - 5 } & & \multicolumn{1}{|c|}{$\begin{array}{c}\text { Aspergillus } \\
\text { niger }\end{array}$} & $\begin{array}{l}\text { Fusarium } \\
\text { oxyspourm }\end{array}$ & Fusarium solani \\
\hline 1. & WCTS21 & 44.44 & 34.37 & 51.66 \\
\hline 2. & WCTS31 & 55.55 & 42.18 & 28.33 \\
\hline 3. & WCTS33 & 55.55 & 21.87 & 15.00 \\
\hline 4. & PCTS13 & 60.00 & 37.50 & 43.33 \\
\hline 5 & PCTS21 & 48.88 & 37.50 & 15.00 \\
\hline 6. & PCTS25 & 75.55 & 34.37 & 23.33 \\
\hline 7. & KCTS15 & 44.44 & 37.50 & 46.66 \\
\hline 8. & KCTS34 & 44.44 & 34.37 & 28.33 \\
\hline
\end{tabular}


Fig.1 Amylase activity of endophytic fungi
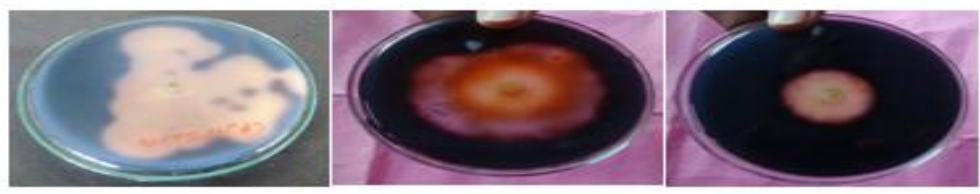

WCTS 21

WCTS 31

WCTS 33
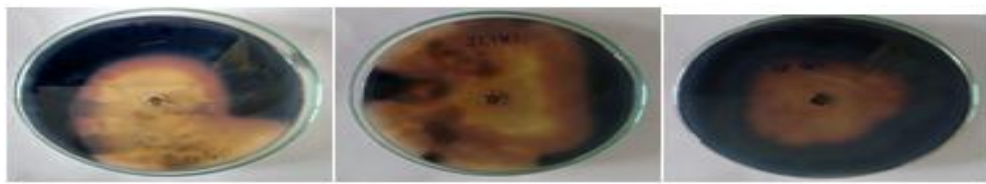

PCTS13

KCTS15

PCTS2 1
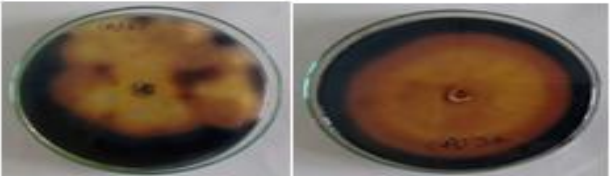

KCTS34

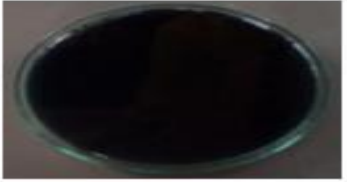

PCTS25

Control

Fig.2 Protease activity of endophytic fungi

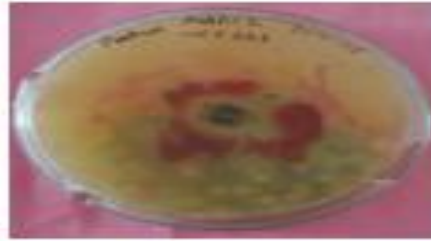

WCTS2 1

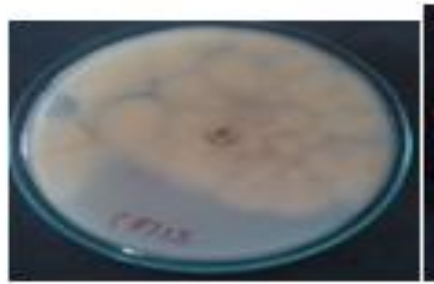

PCTS13

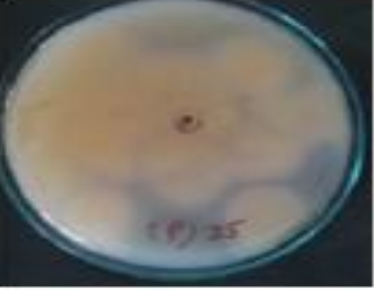

PCTS25

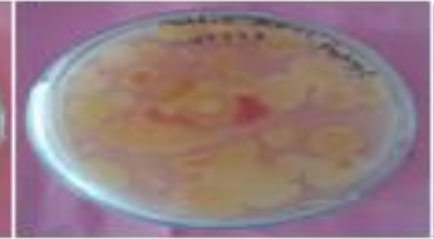

WCTS3 1

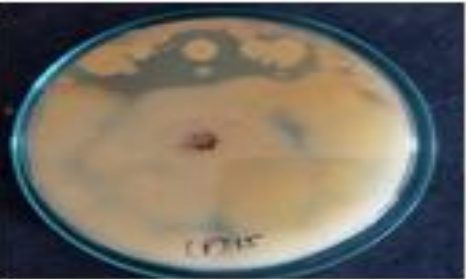

KCTS 15

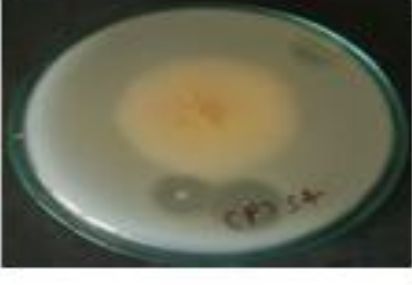

KCTS34

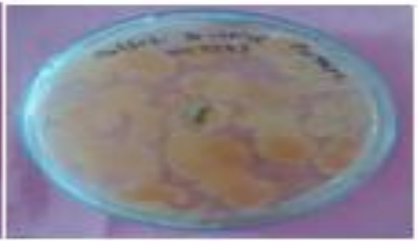

WCTS33

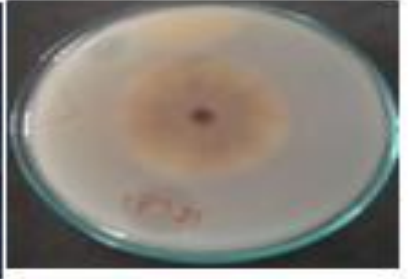

PCTS2 1

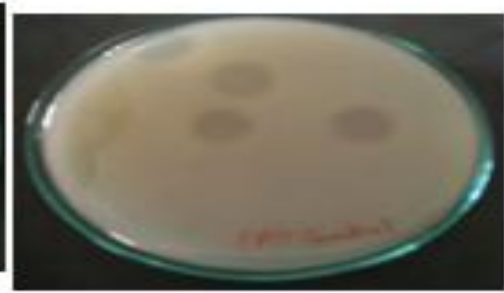

Control 
Fig.3 Lipase activity of Endophytic fungi

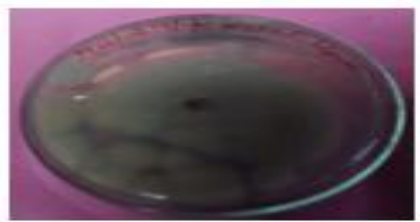

WCTS2 1

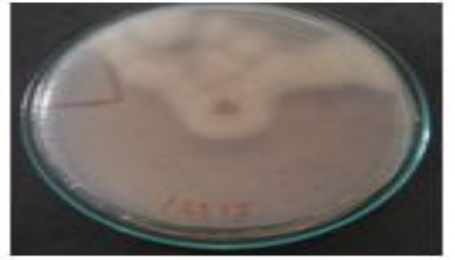

PCTS 13

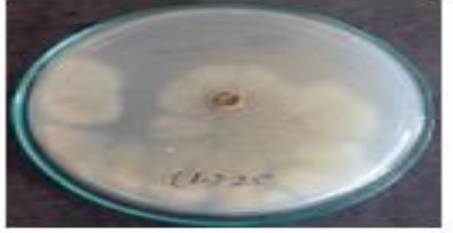

PCTS25

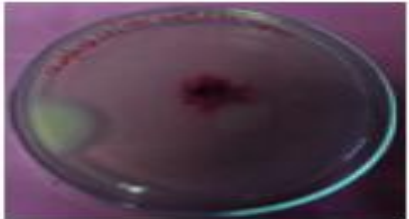

WCTS 31

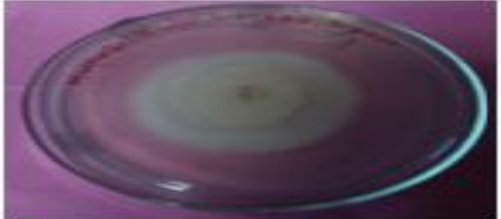

WCTS 33

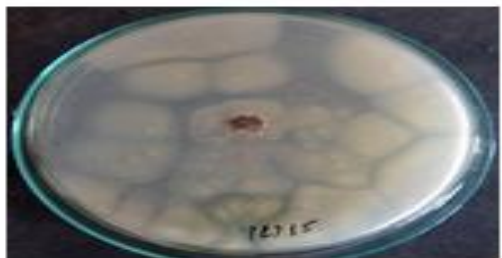

KCTS 15

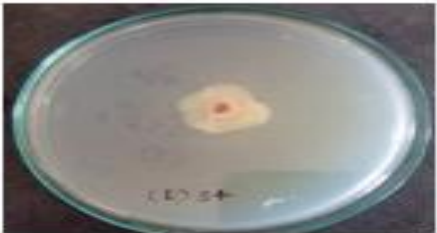

KCTS 34

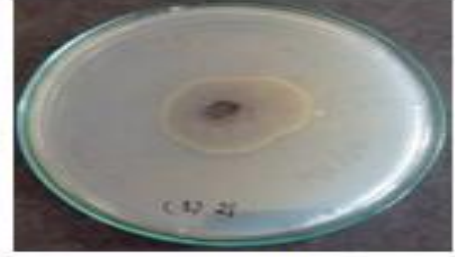

PCTS2 1

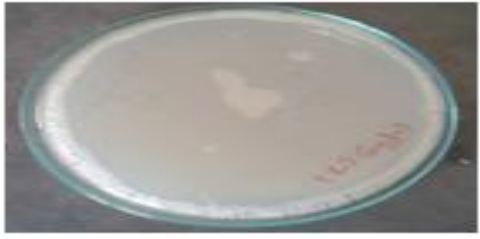

Control

Fig.4 Cellulase activity of endophytic fungi

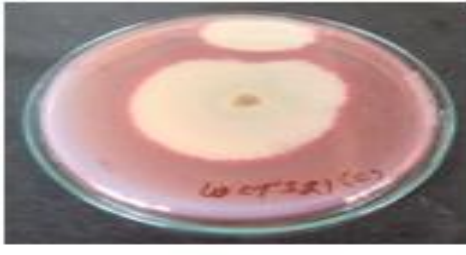

WCTS2 1

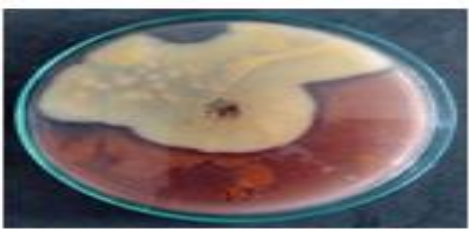

PCTS13

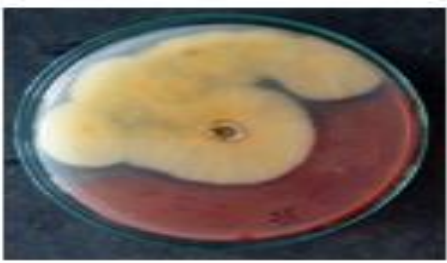

PCTS25

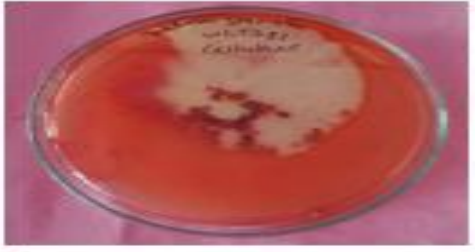

WCTS3 1

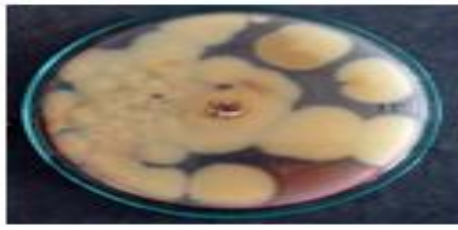

KCTS 15

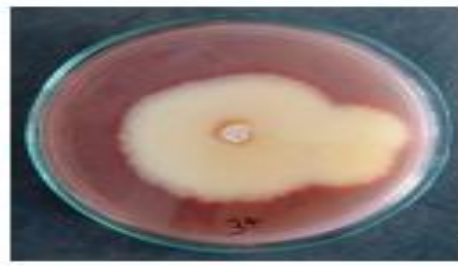

KCTS 34

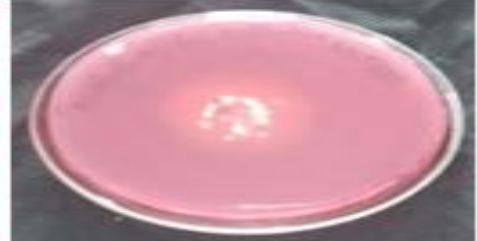

WCTS 33

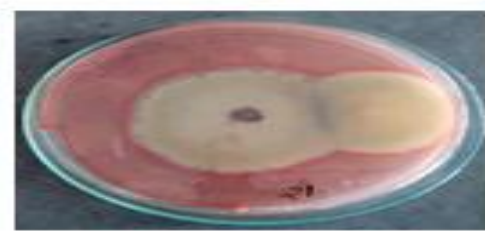

PCTS2 1

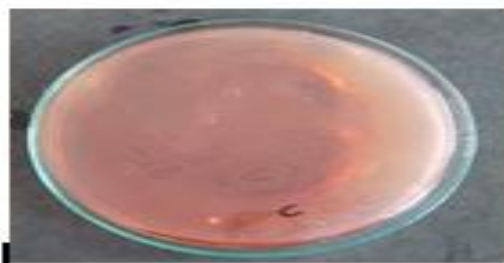

Control 
Fig.5 Chitinase activity of endophytic fungi

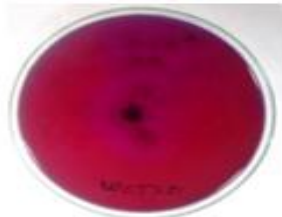

WCTS2 1

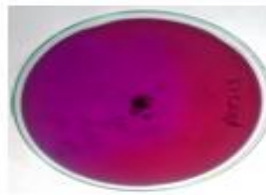

PCTS13

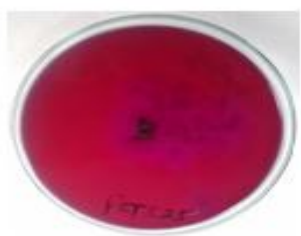

PCTS25

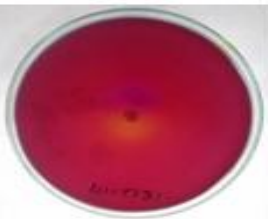

WCTS 31

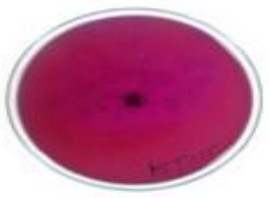

KCTS 15

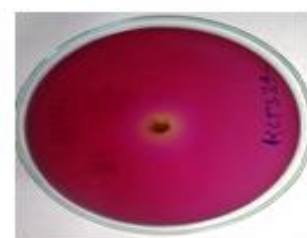

KCTS34

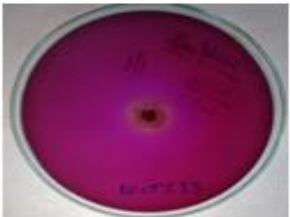

wCTS 33

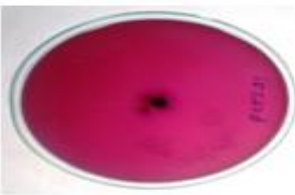

PCTS2

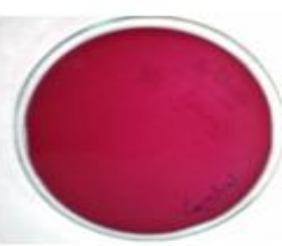

Control

Fig.6 Phosphate solubilizing activity of endophytic fungi

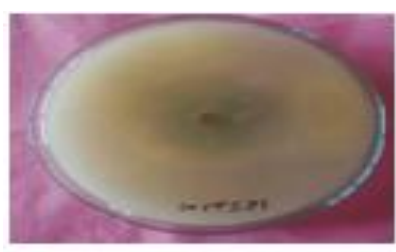

WCTS 21

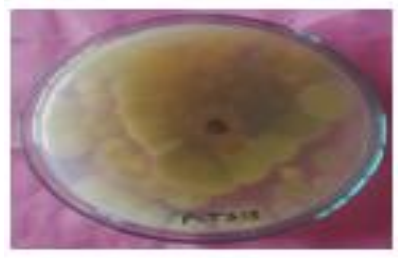

PCTS13

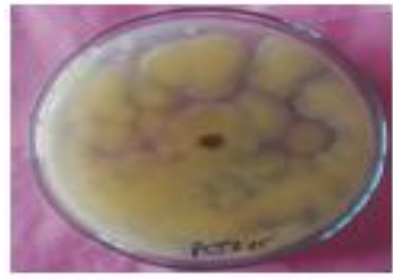

PCTS25

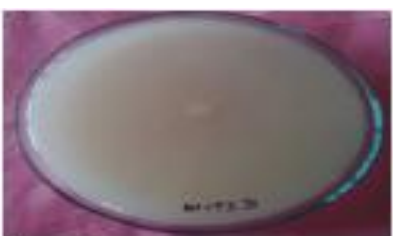

WCTS 31

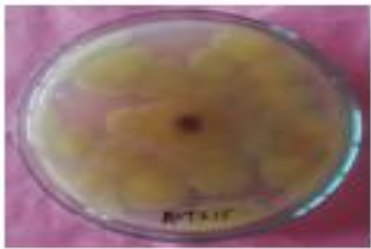

KCTS15

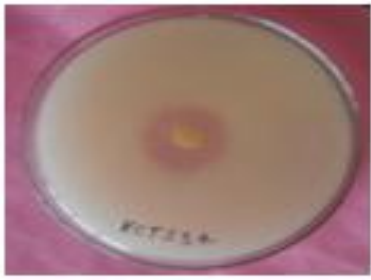

KCTS34

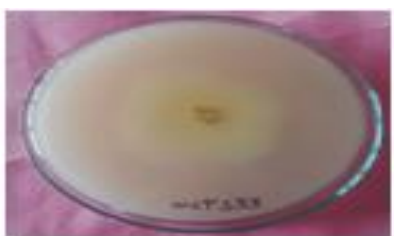

WCTS 33

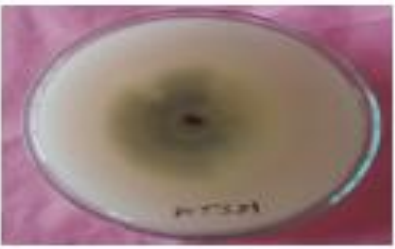

PCTS21

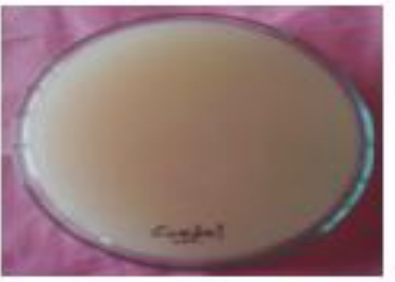

Control 
Int.J.Curr.Microbiol.App.Sci (2017) 6(7): 4084-4100

Fig.7 Ammonia production by endophytic fungi
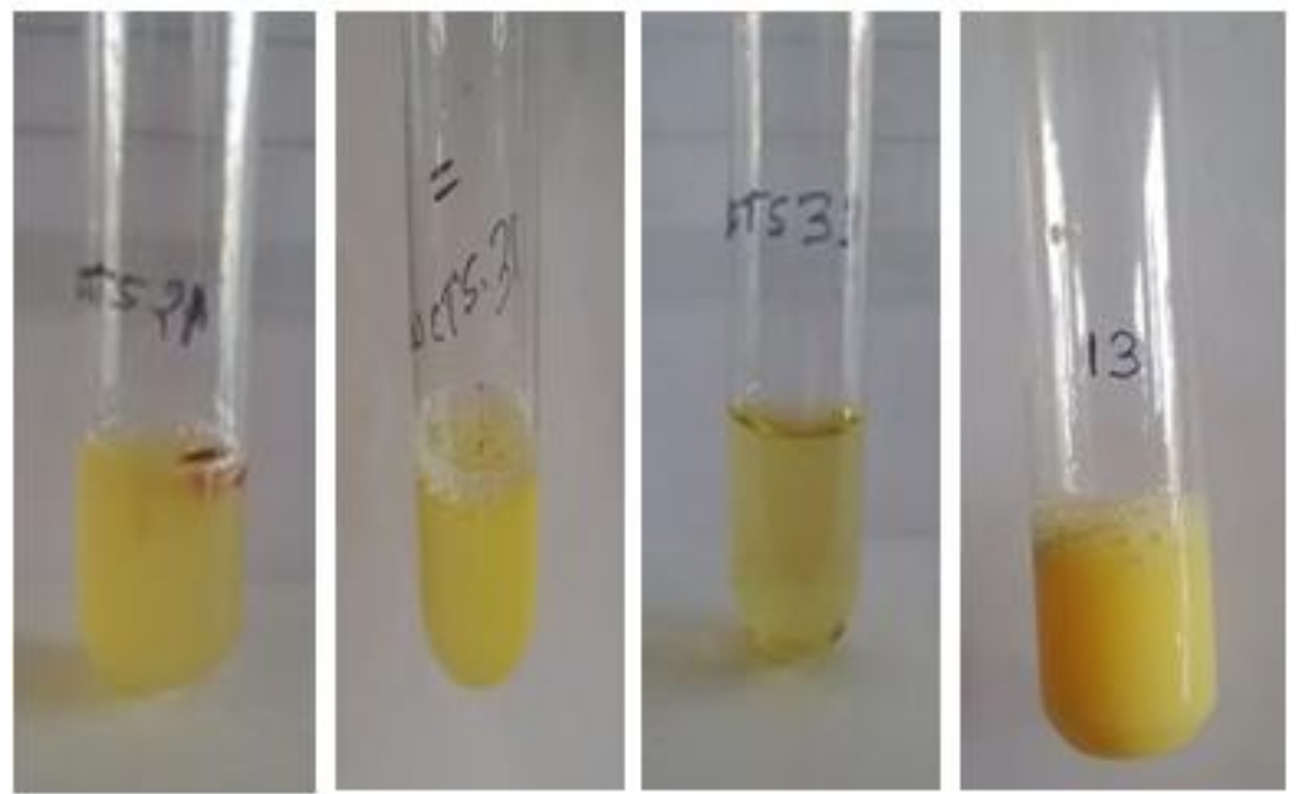

WCTS21

WCTS31

WCTS33

PCTS13
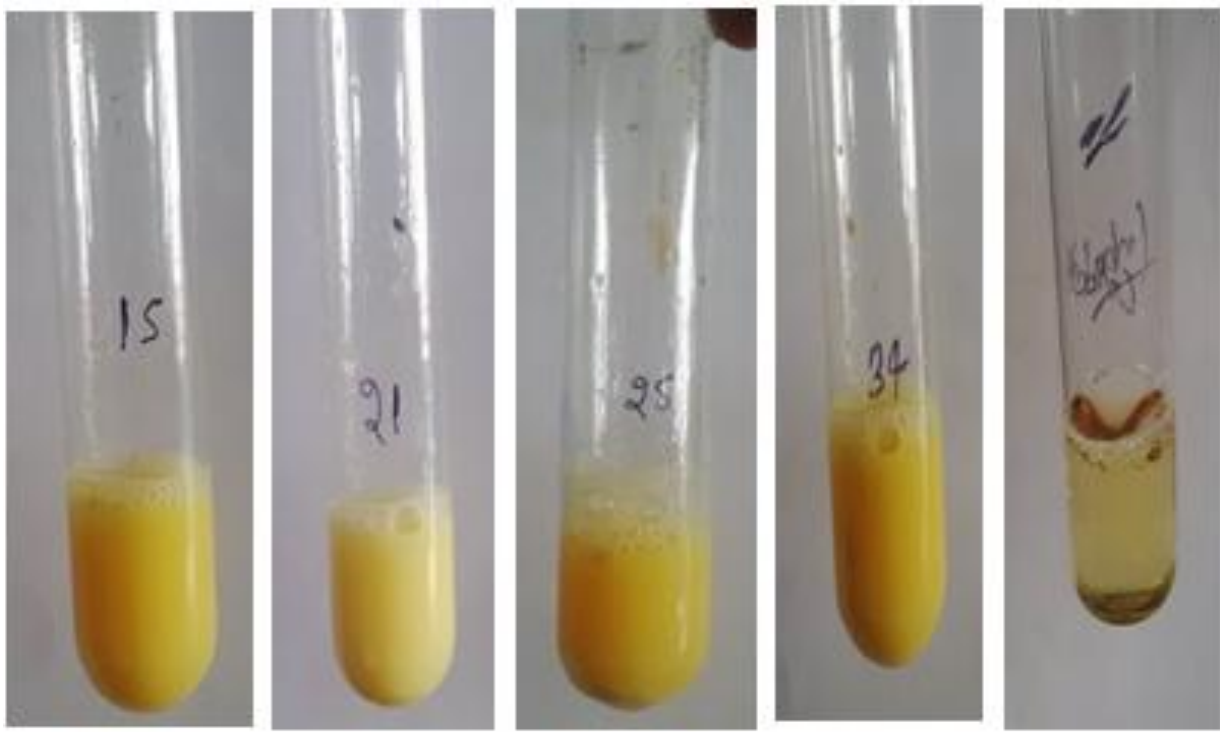

KCTS15

PCTS21

PCTS25

KCTS34

Control 
Fig.8 Production of $\mathrm{HCN}$ by endophytic fungi

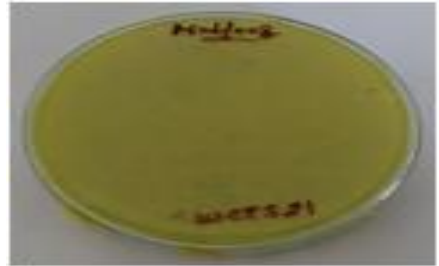

WCTS21

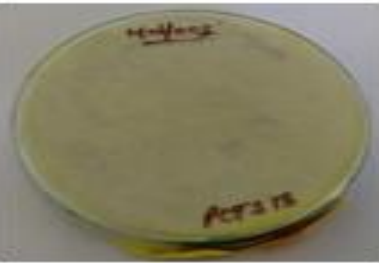

PCTS 13

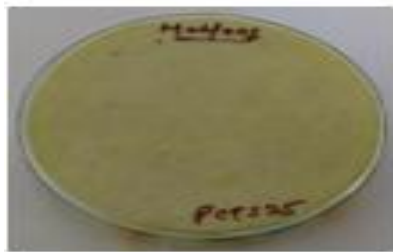

PCTS25

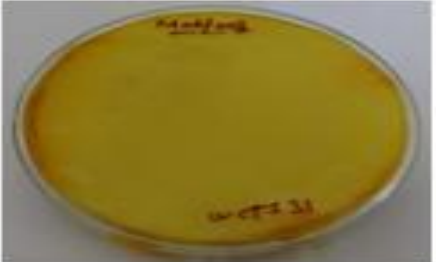

wets 31

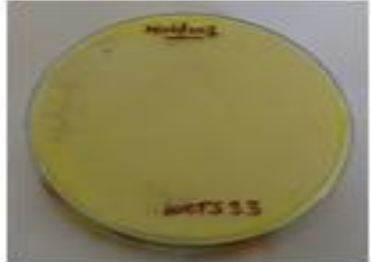

weTs 33

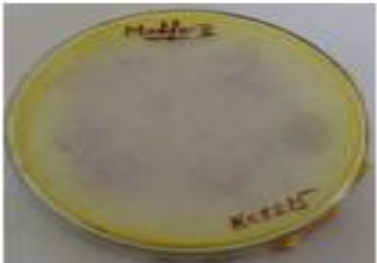

KCTS15

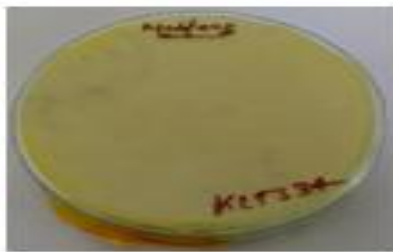

KCTS34

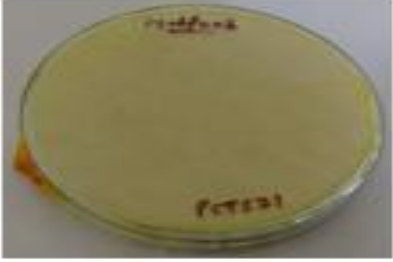

PCTS21

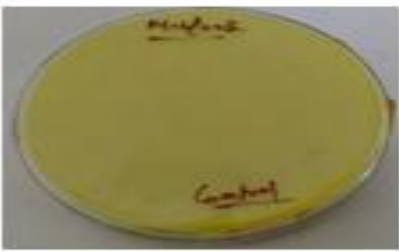

Control

Fig.9 Antagonistic activity of endophytic fungi against fungal pathogen A. niger

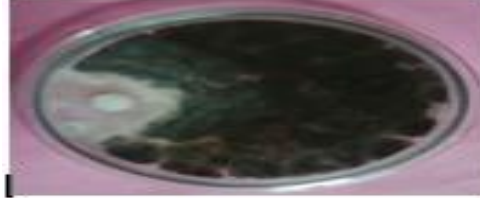

WCTS2 1

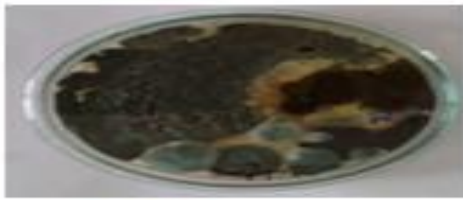

PCTS 13

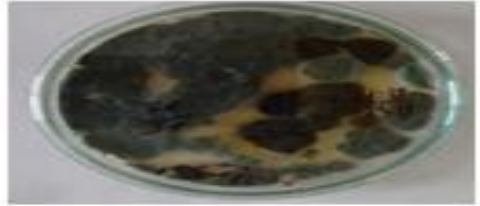

PCTS25

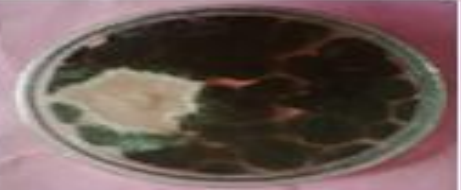

WCTS31

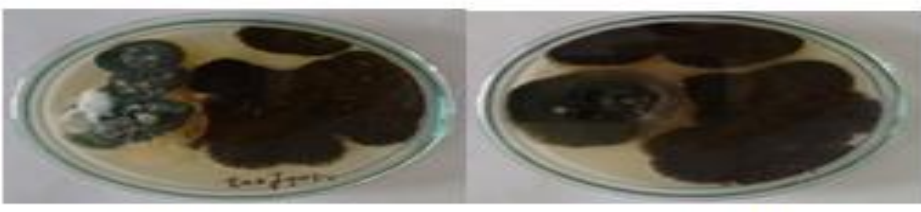

KCTS 15

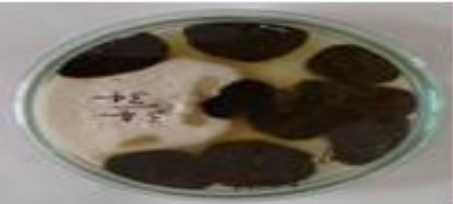

KCTS 34

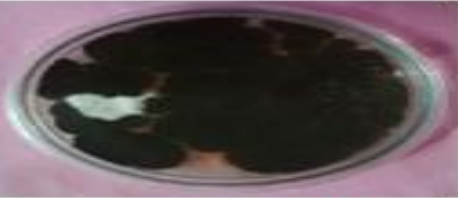

WCTS 33

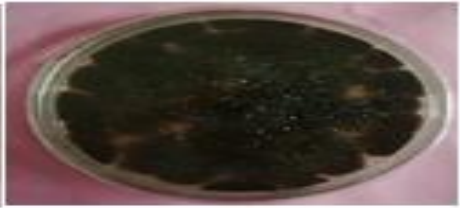

Control 
Fig.10 Antagonistic activity of endophytic fungi against fungal pathogen $F$. oxysporum

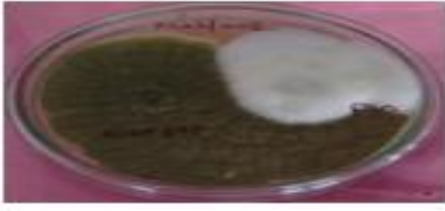

WCTS2 1

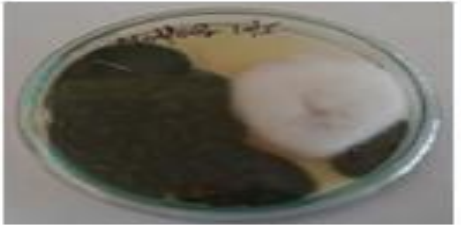

PCTS 13

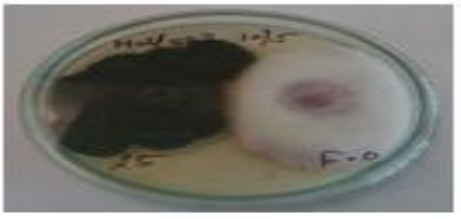

PCTS25

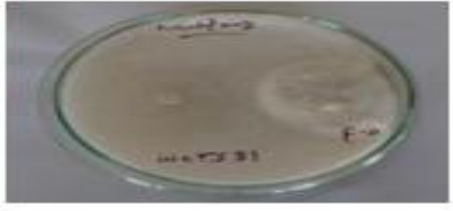

WCTS 31

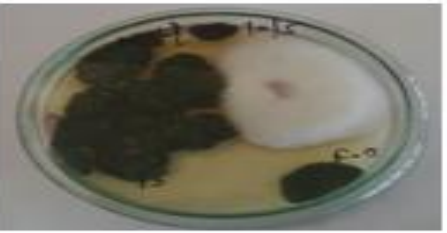

KCTS 15

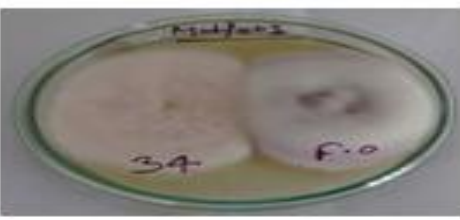

KCTS 34

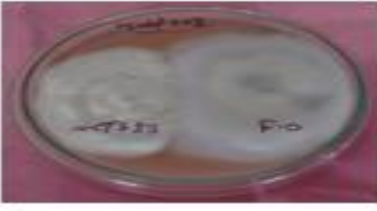

WCTS 33

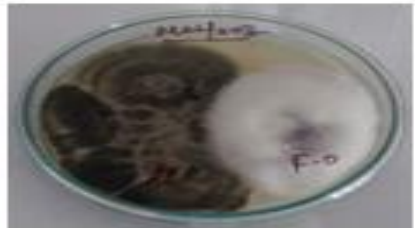

PCTS2 1

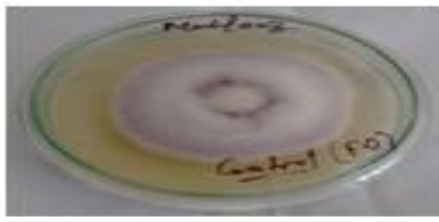

Control

Fig.11 Antagonistic activity of endophytic fungi against fungal pathogen $F$. solani

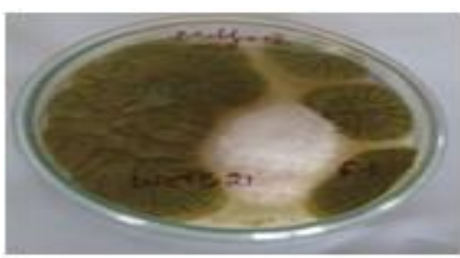

WCTS2 1

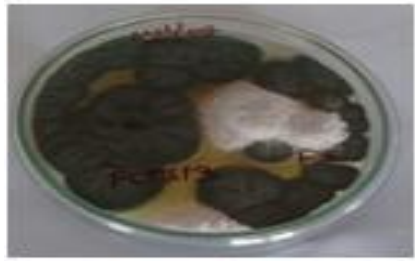

PCTS13

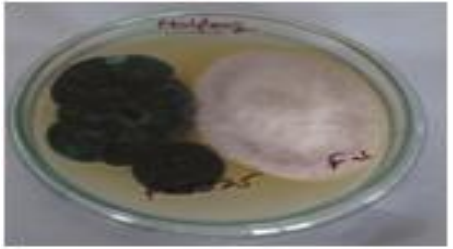

PCTS25

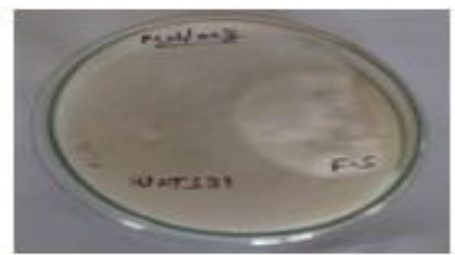

WCTS3 1

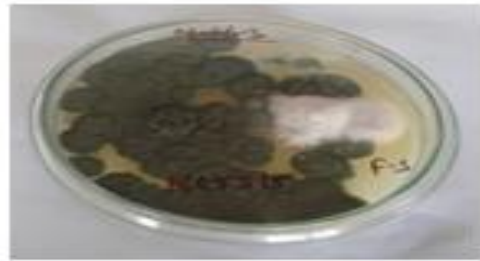

KCTS 15

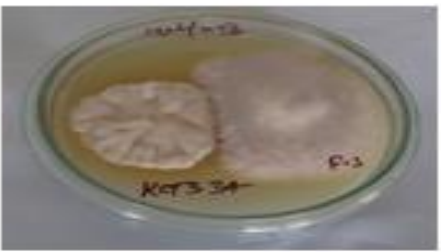

$\mathrm{KCTS} 34$

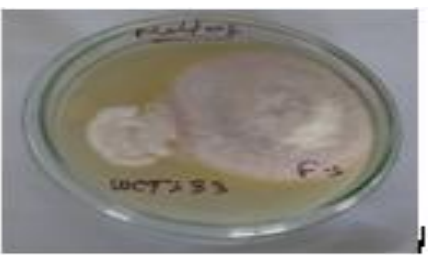

WCTS33

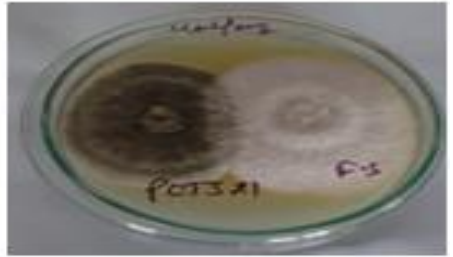

PCTS21

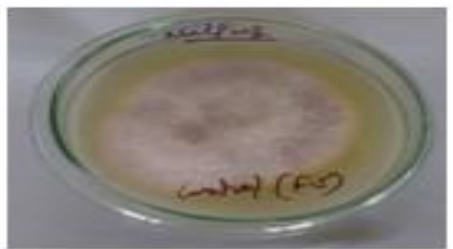

Control 
These endophytic fungal isolates are not pathogens for their antagonism against phytopathogens. These fungi could be adapted to this host and be antagonists of their pathogens. Depending on their antagonistic capacity, they would be able to displace, reduce, suppress or induce resistance against them (Bisht et al., 2016). Those active endophytic fungi inside the plants may play an important role in protecting the plant host against pathogenic microorganisms and have an intimate correlation with the development and physiological activity of wheat (Tian et al., 2004). Antagonism might be due to the production of biologically active compounds in media).

In conclusion, endophytes are being considered for use in biological control, and the extracellular enzymes they secrete might facilitate their initial colonization of internal plant tissues and direct interactions with microbial pathogens. Endophytic fungi produce enzymes which hydrolyses several plant-derived macromolecules and several secondary metabolites. Fungal enzymes are used in textiles, leather industry, food, beverages and confectionaries to simplify the processing of raw materials.

In the present study eight fungal endophytes were screened for qualitatively for the presence of extracellular enzymes such as amylase, protease, lipase and cellulase which has grown in specific medium. The order of enzymes activity found in this study for the isolated microorganism is amylase $>$ cellulose $>$ lipase $>$ protease. Based on the result presented, it can be clearly seen that endophyte isolates from Cupressus torulosa D.Don may be beneficial to the host.

In this study fungal strains also showed several enviable features of plant growth promoting traits and multiple action mechanism which suggests their potential for plant growth promotion. The Results indicated that selected fungi may be helping the plants in protecting from pathogenic fungi. Endophytic fungi PCTS25 identified as Penicillium oxalicum found active in the study can be explored for its potential as a biocontrol agent against $A$. niger, while WCTS33 identified as Pestalotiopsis versicolor and isolate PCTS21 identified as Alternaria alternata showed least antagonistic activity against pathogen Fusarium solani.

\section{References}

Agrawal, P.K., Agrawal, S. 2013. Characterization of Bacillus sp. strains isolated from rhizosphere of tomato plants. Lycopersicon esculentum. for their use as potential plant growth promoting rhizobacteria. Int. J. Curr. Microbiol. App. Sci., 2(10): 406-417.

Agrawal, P.K., Bhardwaj, A., Upadhyay, P., Sharma, D. 2015. Optimization of culture condition for amylase production by Penicillium frequentans AVF2. Kavaka, 44: 45-49.

Agrawal, S., Agrawal, P.K. and Kundan, R. 2015. Characterization of Pseudomonas spp from rhizosphere of Tomato plants. Lycopersicon esculentum. and its efficacy on plant growth promotion. J. Biol. Sci. Scientific Opinion, 3(3):

Almeida, F.B.R., Cerqueira, F.M., Silva, R.N., et al. 2007. Mycoparasitism studies of Trichoderma harzianum against Rhizoctonia solani: evaluation of coiling and hydrolytic enzyme production. Biotechnol. Lett., 29: 1189-1193.

Amirita, A., Sindhu, P., Swetha, J., Vasanthi N.S. and Kannan K.P. 2012. Enumeration of endophytic fungi from medicinal plants and screening of extracellular enzymes. World J. Sci. Technol., 2(2): 13-19.

Arnold, A.E., Henk, D.A., Eells, R.L., Lutzoni, F., Vilgalys, R. 2007. Diversity and phylogenetic affinities of foliar fungal 
endophytes in loblolly pine inferred by culturing and environmental PCR. Mycologia, 99(2): 185-206.

Azevedo, J., Maccheroni, W., Jr, Pereira, J.O., et al. 2000. Endophytic microorganisms: a review on insect control and recent advances on tropical plants. Electron $J$. Biotechnol., 3: 41-65.

Bezerra, J.D.P., M.G.S. Santos, V.M. Svedese, D.M.M. Lima, M.J.S. Fernandes, L.M. Paiva C.M. Souza-Motta, 2012. World J. Microbiol Biotechnol., 28: 1989-1995

Bhardwaj, A., Sharma, D., Jodan, N., Agrawal, P.K. 2015 Antimicrobial and phytochemical screening of endophytic fungi isolated from spikes of Pinus rouxburghii. Arch. Clin. Microbiol., 6(3): 1.

Bisht, R., Sharma, D., and Agrawal, P.K. 2016 antagonistic and antibacterial activity of endophytic fungi isolated from needle of Cupressus torulosa D.don. Asian J. Pharm. Clin. Res., 9(3): 282-288.

Chadha, N., Prasad, R., and Varma, A. 2015. Plant promoting activities of fungal endophytes associated with Tomato roots from Central Himalaya, India and their interaction with Piriformospora Indica.

Choi, Y.W., Hodgkiss I.J. and Hyde, D K. 2005. Enzyme production by endophytes of Brucea javanica. J. Agricultural Technol., 1: 55-66.

Doyle, C. and Butler, M. 1990. The effect of $\mathrm{pH}$ on the toxicity of ammonia to a murine hybridoma. J. Biotechnol., 15: 91-100.

Flores, A.C., Pamphile, J.A., Sarragiotto, M.H., et al. 2013. Production of 3nitropropionic acid by endophytic fungus Phomopsis longicolla isolated from Trichilia elegans A. JUSS ssp. elegans and evaluation of biological activity. World J. Microbiol. Biotechnol., 29: $923-$ 932

Gomathi, S. and Ambikapathy, V. 2011. Antagonistic activity of fungi against Pythium debaryanum. Hesse. isolated from chilli field soil. Adv. Appl. Sci. Res., 2(4): 291-297.

Gupta, R., R.K. Saxena., P. Chaturvedi and J. S. Virdi. 1995. Chitinase production by Streptomyces viridificans: Its potential in fungal cell wall lysis. J. Appl. Bacteriol., 78: 378-383.

Kaur, T., Sharma, D., Kaur, A. and Manhas, R.K. 2013. Antagonistic and plant growth promoting activities of endophytic and soil actinomycetes. Arch. Phytopathol. Plant Protection, 46(14): 1756-1768

Kloepper, J.W. 2009. Plant growth-promotion by rhizobacteria for sustainable agriculture. Rajendranagar, Hyderabad, India: Ranga Agricultural University.

Maria, G.L., Sridhar K.R and. Raviraja N.S 2005. Antimicrobial and enzyme activity of mangrove endophytic fungi of southwest coast of India. J. Agri. Technol., 1: $67-80$.

Meena, B., Marimuthu, T., Vidhyasekaran, P. and Velazhahan, R. 2001. Biological control of root rots of groundnut with antagonistic Pseudomonas fluorescens strains. J. Pl. Dis. Protect., 108: 369-381.

Morissette, D.C., Driscoll, B.T., Jabaji-Hare, S. 2003. Fungal Genet. Biol., 39(3): 276285.

Nadim., Matab, et al., 2015. Extracellular Enzymatic Activity of Tuber maculatum and Tuber aestivum Mycelia. Adv. Microbiol., 5(07): 523.

Nahas, E. 1996. Factors determining rock phosphate solubilisation by microorganism isolated from soil. World J. Microbiol. Biotechnol., 12: 567 -572.

Panuthai, T., Sihanonth, P., Piapukiew, J., Sooksai, S., Sangvanich, P. and Karnchanatat, A. 2012. An extracellular lipase from the endophytic fungi Fusarium oxysporum isolated from the Thai medicinal plant, Croton oblongifolius Roxb. African J. Microbiol. Res., 6(11): 2622-2638. 
Patil., Mohini G., et al., 2015. Extracellular Enzymatic Activities of Endophytic Fungi Isolated from Various Medicinal Plants. Int. J. Curr. Microbiol. App. Sci., 43: 1035-1042.

Pavithra, N., Sathish, L. and Ananda, K. 2012. Antimicrobial and enzyme activity of endophytic fungi isolated from Tulsi. $J$. Pharmaceutical and Biomed. Sci., 16(12).

Petrini, O. 1986. Taxonomy of endophytic fungi of aerial plant tissues. In: Fokkema NJ, van den Huevel J, editors. Microbiology of the phyllosphere. Cambridge: Cambridge University Press; pp. 175-187.

Petrini, O. 1991. Fungal endophytes of tree leaves. J.H. Andrews, S.S Hirano. Eds.), Microbial ecology of leaves, SpringerVerlag, New York, USA, pp. 179198.

Polizeli, M.L.T.M., Jorge, J.A., Terenzi, H.F. 1991. Pectinase production by Neurospora crassa: purification and biochemical characterization of extracellular polygalacturonase activity. J. Gen. Microbiol., 137: 1815-1823.

Schippers, B. 1988. Biological control of pathogens with rhizobacteria. Trans British Soc. Land. B. Biol. Sci., 318: 283293.

Selim, K.A., El-Beih, A.A., AbdEl-Rahman, T.M. and El-Diwany, A.I. 2012. Biology of endophytic fungi. Curr. Res. Environ. Appl. Mycol., 31-82.
Sharma, D., Pramanik, A., and Agrawal, P.K. 2016. Evaluation of bioactive secondary metabolites from endophytic fungus Pestalotiopsis neglecta BAB-5510 isolated from leaves of Cupressus torulosa D.Don. Biotech., 6(2): 210.

Sunitha, V.H.D., Devi, N., and Srinivas, C. 2013. Extracellular enzymatic activity of endophytic fungal strains isolated from medicinal plants. World J. Agri. Sci., 9(1): 01-09.

Tian, X.L., Cao, L.X., Tan, H.M., Zeng, Q.G., Jia, Y.Y., Han, W.Q., et al. 2004. Study on the communities of endophytic fungi and endophytic actinomycetes from rice and their antipathogenic activities in vitro. World J. Microbiol. Biotechnol., 20: 3039.

Tweddell, R.J., Jabaji-Hare, S.H., Charest, P.M. 1994. Appl Environ Microbiol, 60(2): 489-495.

Venkatesagowda, B., Ponugupaty, E., Barbosa, A.M. and Dekker, R.F.H. 2012. Diversity of plant oil seed-associated fungi isolated from seven oil-bearing seeds and their potential for the production of lipolytic enzymes. World J. Microbiol. Biotechnol., 28: 71-80.

Wilson, D. 2000. Ecology of woody plant endophytes. In: Microbial Endophytes. Bacon CW and White JF. Eds.), New York and Basel: Marcel Dekker. pp: 389420.

\section{How to cite this article:}

Mohd Mahfooz, Sushmita Dwedi, Arun Bhatt, Sharad Raghuvanshi, Manoj Bhatt, Pavan Kumar Agrawal. 2017. Evaluation of Antifungal and Enzymatic Potential of Endophytic Fungi Isolated from Cupressus torulosa D. Don. Int.J.Curr.Microbiol.App.Sci. 6(7): 4084-4100. doi: https://doi.org/10.20546/ijcmas.2017.607.424 